\title{
Analysis of Market Structure and Conduct of Date Palm (Phoenix dactylifera, L.) in Jigawa State, Nigeria
}

\author{
Kabir Abdulaziz ${ }^{1 *}$ \\ Amina Mustapha $^{2} \quad$ Aminu Suleiman ${ }^{2}$ \\ Ashafa Salisu Sambo ${ }^{3}$ \\ Mohammed Mustapha Bada ${ }^{4}$ \\ 1.Agricultural Research Council of Nigeria, Plot 223D, Cadastral Zone B6, Mabushi-Abuja, Nigeria \\ 2.Department of Agricultural Economics and Extension, Bayero University, Kano, Nigeria \\ 3.Department of Agricultural Extension and Management, School of Agricultural Technology, Nuhu-Bamalli \\ Polytechnic, Zaria, Samaru-Kataf Campus, Nigeria \\ 4.Bank of Agriculture, Maiduguri Main Branch, Maiduguri, Nigeria \\ *E-mail of the corresponding author: kabeerabdulazeez@yahoo.co.uk
}

The research is financed by the authors.

\begin{abstract}
Analysis of market structure and conduct of date palm was conducted in Jigawa state, Nigeria using multi stage sampling technique which led to the random selection of 121 respondents. All the traders were male, mostly married and within the mean age of 39 years. Majority (42.6\%) of the wholesalers had no formal education, with 12-21 years of marketing experience, while $43.3 \%$ of the retailers had only attended primary school with $2-11$ years marketing experience. High inequality was observed at wholesale $(0.75 \& 0.78)$ and retail $(079 \& 0.75)$ levels. Pest infestation, increased transportation cost and inadequate capital were the major constraints observed. Development of improved varieties that are pests and diseases resistant, provision of appropriate storage, processing, credit and market facilities by all stakeholders, increased local production to boost marketable surpluses to offset demand and ensure all year-round supply of the product and reduced importation were recommended.
\end{abstract}

Keywords: Market, Structure, Conduct, Date Palm, Jigawa State, Nigeria.

DOI: $10.7176 / \mathrm{JMCR} / 79-03$

Publication date:May $31^{\text {st }} 2021$

\section{Introduction}

Date palm is regarded as the most important tree crop of Sahel, Sudan and Guinea Savannah ecologies and is grown extensively in the northern parts of the Nigeria particularly above latitude $10^{\circ} \mathrm{N}$ of the equator (Okolo et. al., 2005). These parts include Jigawa, Kano, and Katsina states. It can also be found in the lower parts of derived savannah areas like Nasarawa, Niger, Plateau and Benue states (Omoti and Okolo, 2000). It is believed that date palm was first introduced into Nigeria in the early $17^{\text {th }}$ century by Arab traders from North Africa through trans-Sahara trade. Date palm is a multi-purpose tree seen as a source of livelihood through the provision of food, shelter, timber products and other industrial raw materials, medicinal and spiritual purposes. Date fruits are regarded as complete food due to its high nutritional content; $77 \%$ carbohydrate (mainly glucose and fructose,), fat $(0.4 \%)$, protein (4\%), pectin (2\%), and fibre (9\%). Dates are good source of vitamin $\mathrm{A}, \mathrm{B}_{1}$ (thiamine), $\mathrm{B}_{2}$ (riboflavin) and $\mathrm{B}_{7}$ (niacin) (Zaid and Wet, 2002) and aluminium, cadmium, chloride, sulphur and oleic acid in various proportions (Salman, 2011).

The Nigerian date palm industry has enormous potential to generate employment and accelerate economic development. However, cultivation remains largely subsistence despite favourable climatic conditions and the existence of local varieties with good yield and fruit qualities. Area under cultivation in Nigeria was estimated at over 1,466ha, with annual production estimated at a little over 21,000MT, which is far below the local demand. As a result, the country largely depends on importation from neighboring countries to close the gap (Abdulqadir et. al., 2011). Date palm in Nigeria is mainly grown for its sweet edible fruits which are very rich in nutrients and energy. It is a high valued economic tree with enormous potentials, thus female palm tree can produce up to 1216 tons of date fruits/ha under good management, depending on the variety and age of the tree, with potential returns of up to $\mathrm{N} 200,000 /$ ha/year depending on fruit quality and prevailing market conditions (Ataga et. al., 2012).

Market structure refers to the organizational characteristics of a market which influence the nature of competition and pricing, and affect the conduct of business firms. Components of market structure include the concentration of market power, degree of product differentiation, entry and exit conditions, flow of information and degree of integration. Market conduct means the patterns of behaviour of firms in relation to pricing and their practices in adapting and adjusting to the market in which they function. It includes market sharing and price setting policies, policies for coercing rivals and policies towards specification of quality of products (Acharya and Agarwal, 2006). 


\subsection{Problem Statement}

Agriculture is arguably the most important sector in Nigeria, its is the largest employer of labour, largest non-oil GDP and foreign exchange earner, largest contributor to wealth creation and poverty alleviation (Adamu, 2013). Date palm production and marketing is a reliable source of income and improved livelihood for the farming households, particularly in the wake of increased demand for food due to rapid rise in population. Date palm marketing offers a good source of income and improved livelihood for the farming households, particularly in the wake of increased demand for food due to unprecedented increase in population. Date palm holds high status among many Nigerian communities especially during ceremonies and festivals (Sani, 2009).

Agricultural development depicts among other things raising agricultural productivity to ensure food security and substantial surpluses. Such surpluses should occur concurrently with adequate storage, processing and distribution to avoid wastage. Ajala and Adesehinwa (2008) reported that marketing systems in developing countries are collusive, exploitative and inefficient. In Nigeria, the degree to which this is true for date palm cannot be said with certainty because the state of information about fruits marketing is largely obtained from studies on other indigenous fruits such as watermelon, pineapple, banana and oranges. This indicates knowledge gap in the date palm industry. Similarly, Nigerian agricultural trade policy is built around mechanisms that ensure food security, promote domestic trade, improve industrial access to agricultural raw materials and promote the use of modern technology and promotion of top-quality agricultural produce for export. In Nigeria, a large number of marketing functions affecting the conduct of marketing are poor, thus restricting responsiveness of marketing processes (Okwoche et. al., 2010). It is safe to say that Nigerian government has not accorded the much-needed attention to date palm industry, particularly marketing and distribution. This reduced its cultivation to compounds, homesteads and a few orchards in the northern parts of the country. The broadest move by government towards the development of date palm industry was its inclusion among the mandate crops of Nigerian Institute for Oil palm Research (NIFOR), Benin City and its substation in Jigawa state. Yet, the substation is mainly into production.

Additionally, there are insufficient studies to towards the functioning and efficiency of dates marketing system, and its supply chain particularly in Jigawa state. It is believed that the bulk of the dates consumed in the state are produced from within, although a substantial amount of the fruit is also imported into the state to make up the demand gap that is left cannot be satisfied by domestic production. The increasing demand for dates can be associated to rapid increase in population which requires more efficient and vibrant marketing systems. Olukosi, et. al., (2005) reported that high marketing costs of trading of agricultural produce is the resultant effect of low marketing efficiency. He further maintained that efficient market system induces rapid economic development by encouraging specialization, which translates into increased output. Farmers may be reluctant to expand production when the marketing system is inefficient as increased production without corresponding development of the marketing system may lead to waste of resources which are known to be limited and having alternative uses. In the light of the above, the study attempted to answer the following research questions:

- What are the socio-economic characteristics of date palm marketers in the study area?

- What is the marketing structure and conduct of date palm in the study area?

- What are the constraints associated with date palm marketing in the study area?

\subsection{Objectives of the Study}

The broad objective of this study was to examine the systems of date palm marketing in Jigawa State. However, the specific objectives were to:

i. Describe the socio-economic characteristics of date palm marketers in the study area,

ii. examine the marketing structure and conduct of date palm in the study area,

iii. identify the constraints associated with date palm marketing in the study area.

\section{Literature Review}

A review of literature aims to serve as foundation of knowledge and provide researchers with the understanding of the scope, conceptual and methodological issues relevant to their field of study. Boote and Beile (2005) opined that detailed and refined review of literature forms the basis and inspiration for a meaningful and useful research, the purpose of which is to illustrate how the subject has been studied previously and what were the gaps.

Mundinamani et. al., (1993) using Bain's classification of markets and Lorenz coefficient of inequality technique analyzed groundnut market in Karnataka. Highly and moderately nature of oligopsonic competition was observed with regards to buyers and slightly concentrated and automatically competing type of markets with regards to sellers. A few bug firms performing multiple functions controlling the major portion of the groundnut trade was observed.

Mandanna (1998) conducted market structure analysis to know the extent of market competition or concentration of two representative tobacco auction markets in Karnataka namely Hunsur and Ramanathapura 
and found to be more towards increased market concentration. Further in the same study, on structural change in India's tobacco exports for the period 1980-81 to 1994-95 using markov chain analysis revealed that USSR was the largest market for Indian unmanufactured tobacco and it showed as a high degree of loyalty for Indian tobacco till 1985-86, which diminished substantially during the period.

Handiganur and Kunnal (1999) in the analysis of market power concentration by the intermediaries revealed that the top four sellers and buyers during lean period controlled more than 50 per cent of the chickpea transacted in all the markets with the exception of Bhalki market. The results of Lorenz coefficient of inequality indicated that the high Lorenz value noticed in some of the markets was the result of few large firms sharing the major quantity of produce transacted and turnover made by them. The low value of Lorenz coefficient in some markets inferred that marketing system of chickpea was most competitive as evident from the fact that arrival in the market is distributed among a greater number of intermediaries. The rejuvenation of cooperative societies by linking of credit with marketing and establishment of Karnataka pulse growers' federations would go a long way in avoiding the concentration of produce in the hand of few traders.

Padmanabhan and Sankaranarayana (1999) studied the market structure for pesticides in Tuticorin district of South Tamil Nadu. In the study, an attempt was made to analyze the market structure of pesticides at retail level and degree of concentration. The market structure of pesticides at retail level was identified as oligopoly, implying that major share of pesticides sales was concentrated with few dealers based on brand name, symbol and color of picking material offered by the firms, as such, the farmers were able to differentiate the pesticides. Competition between the existing retailers in retaining the market share and high investment act as barriers to entry.

Nambiro et. al., (2001) studied marketing conduct of hybrid maize seed in trans Nzoia district in Kenya and observed that seed promotions were mainly undertaken by Kenya seed company and through mass media.

Ham (2003) in South Africa reported that eight per cent of traders (collectors and retailers) engage in presale activities such as cleaning and removing damaged fruits in order to increase the fruits price.

Kibiego et. al., (2003) analyzed the marketing system of bean in urban areas of Kenya and reported that market structure as moderately concentrated with competitive fringe, having observed that in the wholesale trade, the largest four and eight firms controlled 34.76 percent and 59.84 percent of the market share. Thus, the market structure approaches that of pure competition. Additionally, they observed that majority of beans traders (93.7\%) relied on two market information sources; through word of mouth from friends/business colleagues, relatives and by trader's own market.

Mkonda et. al., (2003) in Eastern Zambia observed that determination of fruits prices is dependent on information about prevailing market prices, prices in previous season and other miscellaneous means including harvesting cost.

Gajendran and Kathiravan (2008) studied monopoly power in the duck, egg and meat market structure in Tamil Nadu, the fourth largest duck raising zone in India. Analysis was done by means of concentration ratio (CR) and Hirschman-Herfindahl Index (H Index). In the absence of monopoly, Bain's classification was used to identify the prevailing structure of market. The H-Index computed for eggs at farm level was 0.149 while CR was 0.11 indicating the absence of monopoly. The H-index and CR for duck meat were 0.163 and 0.132 respectively. Despite the presence of atomistically competitive seller and buyer groups, the duck, egg and meat marketing system in Tamil Nadu can be as pure competitive considering the contributing factors such as product differentiation and the degree of market intelligence.

Takele (2010) worked on analysis of rice profitability and marketing chain: the case of Fogera Woerda, South Gondar zone, Amhara national regional state, Ethiopia. Econometrics (Heckman two selection model and probit model) and descriptive analysis consistency were used in the study. Results from the descriptive analyses showed that wholesalers and millers are the most important buyers of rice from producers, about 45 per cent and 27 per cent respectively. The result revealed that the market concentration ratio was 0.77 , showing the rice market to be oligopsonsitic. It also discovered that high initial capital and prior control of farmers acted as a barrier to entry in rice trading. Results from the Heckman's two step selection model showed that, market information access, quantity of paddy produced, total value of livestock unit and extension contact with farmers increase household's probability of selling rice.

Kumar and Gogoi (2011) worked on a case study on consumer buying behavior and brand loyalty with regard to processed liquid packed milk in Guwahati (Assam)'. They concluded that not only the economic factors but also the emotional factors of the consumers like the culture and subculture, habits, likes and dislikes influence the buying behavior of liquid packed milk. These factors can affect the marketing efforts of a firm to a great extent.

Yusefu and Ayanwale (2011) assessed the structure, conduct and profitability associated with the broiler processing market in South western Nigeria in a panel of three years spanning $2004-2006$. The market structure was estimated using the concentration ratio and Gini coefficient. The result of the market structure parameters showed that the concentration ratios (CR4) values were 94.4 per cent, 94.7 per cent and 93.3 per cent in 2004, 
2005 and 2006 respectively, while the Gini coefficient was 0.9 per cent. These parameters indicated that there was a high degree of concentration in the degree implying a monopolistic market structure.

Uloh and Alimba (2018) studied the market structure and conduct of Banana fruits marketing in south east Nigeria and reported Gini-coefficient values of $0.642,0.523$ and 0.538 for producers, wholesalers and retailers respectively, implying that the banana marketing is imperfectly competitive with high inequality in sales and income distribution among marketers. Market information amongst marketers was largely by means of personal observation and from business colleagues.

\section{Materials and Methods}

\subsection{Description of the Study Area}

This study was conducted in Jigawa State, Nigeria. The state is situated in the Northern part of the country, geographically between latitudes $10^{0} 57^{\prime} \mathrm{N}$ to $13^{\circ} 03^{\prime} \mathrm{N}$, longitudes $8^{0} 08^{\prime} \mathrm{E}$ to $10^{\circ} 37^{\prime} \mathrm{E}$ of the equator and has a land area of about $22,210 \mathrm{~km}^{2}$. It is bordered to the north by Katsina state, Yobe state and Niger Republic, to the east and south by Bauchi state and to the west by Kano state (JARDA, 2005). Most parts of the state lies within the Sudan vegetation zone, though traces of Guinea savannah exist on some parts of the southern boundaries. Mean daily temperature is estimated at $27^{\circ} \mathrm{C}$ with minimum and maximum put at $19^{\circ} \mathrm{C}$ and $35^{\circ} \mathrm{C}$ respectively. The maximum temperature has two peaks occurring in April and October, while lowest temperatures are recorded during the months of December and January. Average annual rainfall of about $700 \mathrm{~mm}$, relative humidity can be as high as $80 \%$ in the month of August and as low as $15 \%$ in December and an altitude ranging from 400-600 meters above sea level with solar radiation as high as $24.1 \mathrm{mj} /$ day in February (JARDA, 2005). The climatic conditions of the state are suitable for date palm production due to its tolerance to high temperatures, drought and requires relatively low precipitation.

Jigawa state has an estimated population of 4,348,649 people (NPC, 2006), and it is considered an agrarian state with agriculture being the means of livelihood to over $90 \%$ of the working adults (JARDA, 2005). Popular rain-fed crops include sorghum, millet, cowpea and rice. Crop production during the rainy season is mainly for subsistence with farmers averagely cultivating about 2.5 hectares (Usman, 2009). Major cash crops include date palm, sesame, cowpea, groundnut, Bambara nuts, peppers and bitter lemon. Date palm is strategical placed in the state's economy with an estimated output of 5000MT/annum (Dada, et. al., 2012). Livestock such as cattle, sheep, goats, poultry and donkeys are very common in the state. The major spoken language in the state is Hausa, though, a reasonable number speaks Fulfulde and Kanuri as well (Usman, 2009).

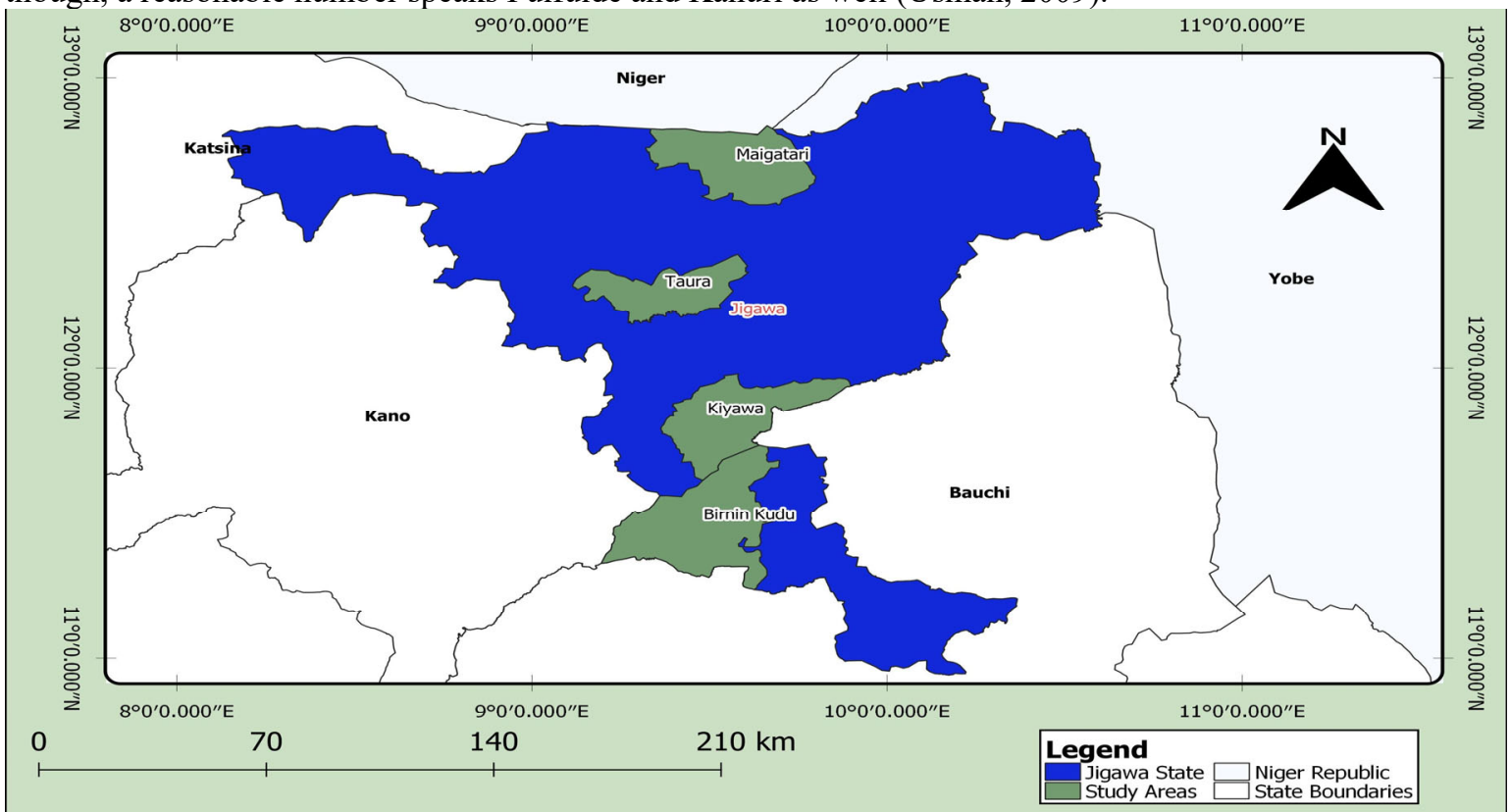

Figure 1: Map of the study area showing the selected Local Government Areas.

\subsection{Sampling Technique}

Multi-stage sampling technique was employed in selecting samples for this study. Four Local Government Areas (LGAs); Kiyawa, Taura, Maigatari, and Birnin Kudu were purposively selected based on availability of markets where date palm is sold in significant quantity. This was followed by purposive selection of four (4) markets; Shuwarin market in Kiyawa, Gujungu market in Taura, Maigatari market in Maigatari, and Babaldo market in Birnin Kudu LGA. The third stage involved random selection of $40 \%$ wholesalers and retailers from each of the 
selected markets, giving a sample size of 54 wholesalers and 67 retailers respectively as indicated in Table 1.

Table 1: Sampling of Date Palm Marketers

\begin{tabular}{|l|c|c|c|c|}
\hline \multirow{2}{*}{ Markets } & \multicolumn{2}{|c|}{ Wholesalers } & \multicolumn{2}{c|}{ Retailers } \\
\cline { 2 - 5 } & Est. population & $\begin{array}{c}\text { Sample size } \\
\mathbf{( 4 0 \%} \text { of EP) }\end{array}$ & Est. population & $\begin{array}{c}\text { Sample size } \\
\mathbf{( 4 0 \%} \text { of EP) }\end{array}$ \\
\hline Shuwarin & 36 & 14 & 47 & 19 \\
\hline Gujungu & 28 & 11 & 37 & 15 \\
\hline Maigatari & 37 & 15 & 54 & 22 \\
\hline Babaldo & 34 & 14 & 27 & 11 \\
\hline Total & $\mathbf{1 3 5}$ & $\mathbf{5 4}$ & $\mathbf{1 6 5}$ & $\mathbf{6 7}$ \\
\hline
\end{tabular}

Source: Field survey, 2018. *EP = Estimated population

\subsection{Data Collection}

Data for this study were obtained from primary source using structured questionnaires with the aid of trained enumerators. The questionnaires were administered to collect information on socio-economic characteristics, market information, costs, prices and constraints of date palm marketing.

\subsection{Data Analysis}

Data collected for the study were analyzed using descriptive statistics, Gini coefficient. Descriptive statistics was used to achieve objective I and III, and Gini coefficient was used to achieve objective II.

3.4.1 Descriptive statistics

Descriptive statistics such as mean, frequency distribution, percentages and standard deviation were used to describe the socio-economic characteristics of date palm marketers and constraints to date palm marketing in the study area.

\subsubsection{Gini coefficient (G.C)}

Gini coefficient was developed by an Italian statistician, Corrado Gini in 1912 and it is the most commonly used measure of inequality among values that are frequently distributed, e.g., income. The coefficient varies between 0 , which reflects complete equality and 1 , which indicates complete inequality (one person has all income or consumption, all others have none). Gini coefficient was used to examine the level of inequality or otherwise in date palm marketing. Previous studies including that of Blessing and Shulammite (2012) reported that Gini coefficient is computed using the formula:

$$
\text { G.C }=1-\sum X Y
$$

Where:

G.C $=$ Gini coefficient

$\mathrm{X}=$ Proportion of date fruits marketers,

$\mathrm{Y}=$ Proportion of date fruit marketers' sales,

$\sum=$ Summation sign

\section{Results and Discussion}

4.1 Socio-economic Characteristics of Date Palm Marketers

This section describes the socio-economic characteristics of date palm marketers in the study area. The quantitative and qualitative socioeconomics characteristics of the respondents are presented in Table 2 and 3 respectively. The variables covered include age, gender, marital status, household size, major occupation, marketing experience and educational attainment of the marketers. 
Table 2: Quantitative Socioeconomic Characteristics of Date Palm Marketers

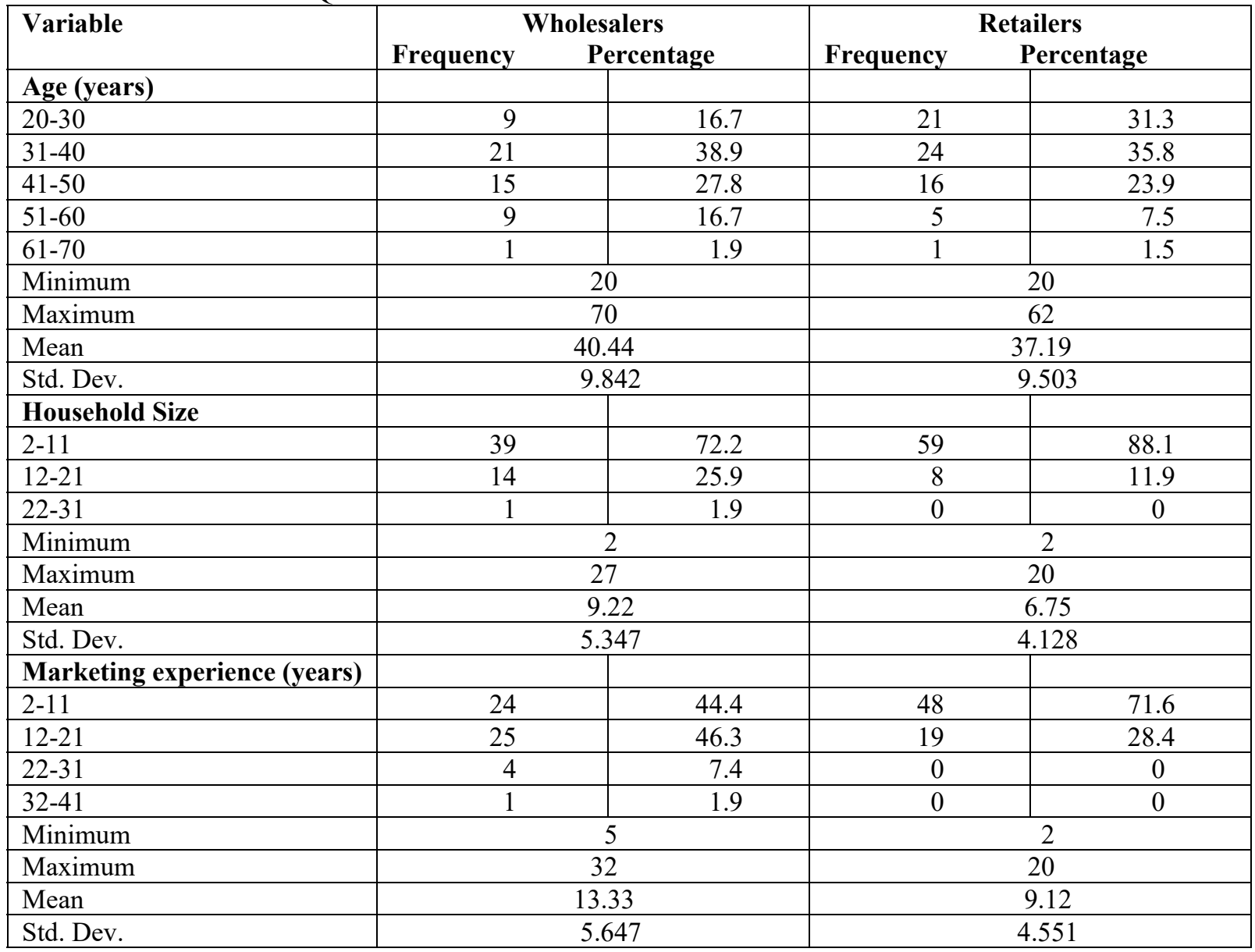

Source: Field survey, 2018

4.1.1 Age of date palm marketers

Age of date palm marketers could to a certain degree affect their marketing ability as it involves interaction with different classes of actors in and outside markets. Results from Table 2 revealed that age of date palm wholesalers in the study area fell between 20 and 70 years, and between 20 and 62 years for retailers. The mean ages of wholesalers and retailers were 40 and 37 years, with standard deviation of 9.842 and 9.503, respectively. The result further revealed that most of the wholesalers and retailers were within the age of 31-40 years, representing 38.9 percent and 35.8 percent, respectively. This shows that most of the marketers are within their economically active age and thus should be able to execute their marketing functions effectively. FAO (1993) defined economically active population to be within 15-64 years.

4.1.2 Household size of date palm marketers

Household size is an important socioeconomic parameter in marketing that can determine the food security status of the household. This is because large household size indicates greater social responsibility on the household head. Distribution of date palm marketers on the basis of their household sizes is also presented in Table 2. The results indicated that majority of the wholesalers and retailers had household sizes ranging from 2-11 persons, representing 72.2 percent and 88.1 percent, respectively. The minimum, maximum and mean household sizes were 2, 27 and 9 for wholesalers, and 2, 20 and 7 for retailers, respectively. Muhammed (2012) reported that mean household size of Gum Arabic traders was 8.43. Abdu (2006) further reported that the mean household size in savannah zone of Nigeria was 10 . He further stressed that variation in household size may be as a result of polygamous nature of most households in Nigeria due to culture and religion.

4.1.3 Marketing experience

Years of experience has a profound influence on the managerial ability and decision making in marketing of agricultural commodities. Adesina and Kehinde (2008) opined that marketing experience enhances proper utilization of scares resources, economic decision making, and timely assessment of alternatives. High proportion of the wholesalers $(46.3 \%)$ had marketing experience ranging from 12-21 years, while majority of the retailers $(71.6 \%)$ had marketing experience within the range of 2-11 years as outlined in Table 2 . This implies that there could be sustainability of the enterprise through transfer of knowledge and skills to the younger generation. Abdulsalam (2004) reported that people gain more expertise and mastery with experience in their 
profession. He further stated that experience influences a person's perception and understanding of climatic, socioeconomic policies and factors that affect their vacation over the years. This concurs with Adeoye et. al., (2009) who reported that $69 \%$ of wholesalers had 1-15years experience, while $50 \%$ of retailers had 6-10years experience. The minimum and maximum years of experience were 5 and 32 for wholesalers and, 2 and 20 for wholesalers, while the mean was 13.33 and 9.12 years respectively.

\subsubsection{Gender of date palm marketers}

Gender implies the categorization of human race or organisms into males and females. The study revealed that date palm marketing (wholesaling and retailing) is completely dominated by male traders (100\%) in the study area. This indicates that women were secluded in their houses due to religious and socio-cultural background and thus cannot take the risk of sourcing and trading of the commodity in the study area. Additionally, outdoor marketing is tedious and involves mingling with males of different background and character, a situation that is seen strange in northern Nigeria and particularly Jigawa state due to religious and socio-cultural setting of the state. As a result, females are mostly found to be involved in less tedious and indoor activities as well as postharvest operations. Ejembi et al., (2006) found women's participation in produce marketing to be unpronounced.

Table 3: Qualitative Socioeconomic Characteristics of Date Palm Marketers

\begin{tabular}{|c|c|c|c|c|}
\hline \multirow[b]{2}{*}{ Marital status } & \multicolumn{2}{|c|}{ Wholesalers } & \multicolumn{2}{|c|}{ Retailers } \\
\hline & Frequency & Percentage & Frequency & Percentage \\
\hline Single & 2 & 3.7 & 16 & 23.9 \\
\hline Married & 52 & 96.3 & 51 & 76.1 \\
\hline \multicolumn{5}{|l|}{ Major occupation } \\
\hline Farming & 7 & 13.0 & 19 & 28.4 \\
\hline Trading & 1 & 1.9 & 0 & 0.0 \\
\hline Date Palm Marketing & 45 & 83.3 & 48 & 71.6 \\
\hline \multicolumn{5}{|l|}{ Level of education } \\
\hline Primary & 17 & 31.5 & 29 & 43.3 \\
\hline Secondary & 12 & 22.2 & 10 & 14.9 \\
\hline Tertiary & 2 & 3.7 & 2 & 3.0 \\
\hline No formal education & 23 & 42.6 & 26 & 38.8 \\
\hline \multicolumn{5}{|c|}{ Membership to marketing association } \\
\hline Registered & 18 & 33.3 & 17 & 25 \\
\hline Not registered & 36 & 66.7 & 50 & 75 \\
\hline \multicolumn{5}{|l|}{ Source of initial capital } \\
\hline Personal savings & 49. & 90.7 & 53 & 79.1 \\
\hline Friends \& relatives & 9 & 5.6 & 3 & 13.4 \\
\hline Adashi & 0 & 0.0 & 1 & 1.5 \\
\hline $\begin{array}{l}\text { Personal savings }+ \text { Friends \& } \\
\text { Relatives }\end{array}$ & 2 & 3.7 & 3 & 4.5 \\
\hline Others (Farming proceeds) & 0 & 0.0 & 1 & 1.5 \\
\hline
\end{tabular}

Source: Field survey, 2018

4.1.5 Marital status of date palm marketers

Conventionally, marriage is believed to make an individual more responsible and takes relatively technical decisions more accurately. Results from Table 3 further indicated that majority of the wholesalers and retailers were married with 96.3 percent and 76.1 percent respectively. This implies that majority of the date palm marketers were responsible men and can make rational decisions with high accuracy on their own, this could in turn increase their efficiency.

4.1.6 Major occupation of date palm marketers

Occupation of a trader is an important determinant of his/her income and ability to save and invest in his/her business, though many argue that saving is not also influenced by occupation. Makerere (2004) defined occupation as an individual's source of livelihood and where such an individual spends much of his/her time. Table 3 also shows the distribution of the marketers based on their major occupation. The results revealed that the greatest proportion of both the wholesalers and retailers, with 83.3 percent and 76.1 percent respectively had date palm trading as their major occupation. This could lead to professionalism in the trade, since the more frequently you engage in an occupation the more your level of expertise in such occupation. 


\subsubsection{Level of education of date palm marketers}

Education enables an individual to accept a paradigm shift away from traditional to modern methods of marketing. Biran (1995) reported that educational attainment is paramount in respondent's decision making. Education is very important in every human endeavor as an avenue through which technology is conveyed. Adesina and Kehinde (2008) asserted that education is important in the objective analysis of problem, planning and implementation of the decision and evaluation of the results especially if it is functional in whatever business an individual engages.

Results in Table 3 similarly outlined the distribution of the date palm marketers on the basis of their educational status. The result shows that 42.6 percent of the wholesalers had no formal education, while 43.3 percent of the retailers had only primary education. This implies that most of the respondents had little or no formal education, but are skilled in their marketing activities. This could affect their efficient utilization of credit facilities. Formal education has influence on better understanding and adoption of new marketing technologies and strategies of date palm marketing in addition to improving enterprise through proper record keeping. This finding is in agreement with Muhammed (2012), who reported that 54 percent of marketers have no formal education in his study on Gum Arabic marketing in Kano State.

\subsubsection{Membership to marketing association}

Further presented in Table 3 is the distribution of the traders based on their membership to marketing association. The result indicated that only 33.3 percent of the wholesalers and 25 percent of the retailers belongs to date palm marketing association in the study area.

\subsubsection{Source of initial capital}

The result on the source of initial capital of the traders shows as outlined in Table 3 that 90.7 percent of the wholesalers sourced their initial capital from personal savings, 5.6 percent and 3.7 percent from friends and relatives, and a combination of personal savings and friends and relatives respectively. Similarly, 79.1 percent of the retailers obtained their initial capital through personal savings, 13.4 percent from friends and relatives, and 4.5 percent from a combination of personal savings and support from friends and family. This indicated that government, commercial banks and cooperative societies do not offer any financial support in date pam marketing.

\subsection{Source of Date Palm}

Source of date palm refers to the place where the dates are purchased or brought from by the wholesalers and retailers. Table 4 presents the different sources of date palm in the study area.

Table 4: Source of date palm

\begin{tabular}{|l|c|c|}
\hline Sources & \multicolumn{1}{|c|}{ Frequency } & Percentage \\
\hline Wholesalers & 10 & 18.52 \\
\hline Local Farmers + Importers & 30 & 55.56 \\
\hline Importers & 3 & 5.50 \\
\hline Local farmers + Niger Rep & 2 & 3.70 \\
\hline Local farmers + Importers + Commission agents & 6 & 11.11 \\
\hline Niger Rep. (self-imported) & 3 & 5.56 \\
\hline Importers + Commission agents & & \\
\hline & & 11.94 \\
\hline Retailers & 8 & 80.60 \\
\hline Local farmers + Wholesalers & 54 & 1.49 \\
\hline Wholesalers & 1 & 5.97 \\
\hline Other source (Kano) & 4 & \\
\hline Commission Agents & & \\
\hline
\end{tabular}

Source: Field Survey, 2018

The results in Table 4 revealed that majority of the wholesalers $(55.56 \%)$ sourced their date palm from importers, while only 3.70 percent sourced dates through farmers, importers and commission agents. Similarly, the result further revealed that majority of the retailers $(80.60 \%)$ sourced their dates from wholesalers and only 1.49 percent sourced their dates from other states, specifically Kano state.

\subsection{Market Structure Analysis}

Market structure refers to those characteristics of market that significantly affects the interaction between buyers and sellers. Acharya and Agarwal (2006) opined that market structure sum up the characteristics of organization of the market that exerts strategic influence on the nature of competition and pricing in the market. In most cases, parameters such as number and size of sellers and buyers, type of the product, entry and exit conditions and transparency of information are taken into account in determining market structure and conduct. 


\subsubsection{Number and size of market participants}

The surveyed markets were found to have numerous buyers and sellers. Gini coefficient was used to estimate the number and size of the market share of the participants as indicated in Table 5.

Table 5: Estimation of Gini Coefficient for Wholesalers and Retailers

\begin{tabular}{|c|c|c|c|c|c|c|}
\hline \multicolumn{7}{|c|}{ Gini Coefficient for Wholesalers } \\
\hline $\begin{array}{c}\text { Range of } \\
\text { Sales (N/Kg) }\end{array}$ & $\begin{array}{c}\text { No. of } \\
\text { Marketers }\end{array}$ & $\begin{array}{c}\text { Ave. Value } \\
\text { of Sales }\end{array}$ & $\begin{array}{c}\text { Prop. of } \\
\text { Marketers (X) }\end{array}$ & $\begin{array}{c}\% \text { Ave. } \\
\text { sales (Y) }\end{array}$ & $\begin{array}{c}\text { Cum. \% } \\
\text { Sales }\end{array}$ & $\sum X Y$ \\
\hline \multicolumn{7}{|c|}{ Peak Period } \\
\hline $300-500$ & 5 & 400 & 0.09 & 0.14 & 0.14 & 0.01 \\
\hline $501-700$ & 28 & 601 & 0.52 & 0.21 & 0.36 & 0.11 \\
\hline $701-900$ & 13 & 801 & 0.24 & 0.29 & 0.64 & 0.07 \\
\hline $901-1,100$ & 8 & 1,001 & 0.15 & 0.36 & \begin{tabular}{l|l}
1.00 & \\
\end{tabular} & 0.05 \\
\hline & & & & \multicolumn{3}{|c|}{$\mathrm{GC}=1-0.25=0.75$} \\
\hline \multicolumn{7}{|c|}{ Off-peak Period } \\
\hline $300-500$ & 17 & 400 & 0.31 & 0.14 & 0.14 & 0.04 \\
\hline $501-700$ & 25 & 601 & 0.46 & 0.21 & 0.36 & 0.10 \\
\hline $701-900$ & 4 & 801 & 0.07 & 0.29 & 0.64 & 0.02 \\
\hline $901-1,100$ & 8 & 1,001 & 0.15 & 0.36 & 1.00 & 0.05 \\
\hline & & & & \multicolumn{3}{|c|}{$\mathrm{GC}=1-0.22=0.78$} \\
\hline \multicolumn{7}{|c|}{ Gini Coefficient for Retailers } \\
\hline $\begin{array}{c}\text { Range of } \\
\text { Sales (N/Kg) }\end{array}$ & $\begin{array}{c}\text { No. of } \\
\text { Marketers }\end{array}$ & $\begin{array}{c}\text { Ave. Value } \\
\text { of Sales }\end{array}$ & $\begin{array}{c}\text { Prop. of } \\
\text { Marketers (X) }\end{array}$ & $\begin{array}{l}\text { \% Ave. } \\
\text { sales (Y) }\end{array}$ & $\begin{array}{ll}\text { Cum. } & \% \\
\text { Sales } & \\
\end{array}$ & $\sum \mathbf{X Y}$ \\
\hline \multicolumn{7}{|c|}{ Peak Period } \\
\hline $300-500$ & 18 & 400 & 0.27 & 0.14 & 0.14 & 0.04 \\
\hline $501-700$ & 38 & 601 & 0.57 & 0.21 & 0.36 & 0.12 \\
\hline $701-900$ & 8 & 801 & 0.12 & 0.29 & 0.64 & 0.03 \\
\hline $901-1,100$ & 3 & 1,001 & 0.04 & 0.36 & 1.00 & 0.02 \\
\hline & & & & \multicolumn{3}{|c|}{$\mathrm{GC}=1-0.21=0.79$} \\
\hline \multicolumn{7}{|c|}{ Off-peak Period } \\
\hline $300-500$ & 2 & 400 & 0.03 & 0.14 & 0.14 & 0.00 \\
\hline $501-700$ & 36 & 601 & 0.54 & 0.21 & 0.35 & 0.12 \\
\hline $701-900$ & 26 & 801 & 0.39 & 0.29 & 0.64 & 0.11 \\
\hline $901-1,100$ & 3 & 1,001 & 0.04 & 0.36 & 1.00 & 0.02 \\
\hline & & & & \multicolumn{3}{|c|}{$\mathrm{GC}=1-0.25=0.75$} \\
\hline
\end{tabular}

Source: Field survey, 2018

The wholesaler Gini coefficients for peak and off-peak periods were 0.75 and 0.78 respectively. The Gini coefficients of 0.75 and 0.78 indicates high level of inequality in earnings from the sales of the product as indicated in Table 5. This further indicates existence of market imperfection, such that no single trader is large enough to have market power to set price of the product.

Similarly, Gini coefficient for retailers at peak and off-peak periods is outlined in Table 5. Coefficients of 0.79 and 0.75 at peak and off-peak periods respectively is an indication of high inequality in earnings realized from the sales of the product and imperfect competition, which may further affect the performance of the market. The result is supported by Muhammed (2012) who reported inequality and imperfection in Gum Arabic marketing in Kano state.

4.3.2 Identification of different types, varieties and forms of date palm in Jigawa State

Two types of dates (local and foreign) were traded in the selected markets of the state; the local varieties and imported or foreign varieties of dates. The most widely traded dates in the study area were the foreign types and are usually dry in form. These include Dan Agadas (from Nger republic), Digila (Deglet Noor from Algeria), Dan Mali (Empress from Mali) and Targal (Tagyal).

It was observed that processed date fruits which are usually more expensive than the unprocessed ones were not found in any of the surveyed markets. This could be as a result of low demand for processed dates when compared to their unprocessed counterparts. The predominance of foreign type of dates in the study area implies its high rate of importation into the country. This could also be partly because the state shares border with Niger republic and Mali.

The attributes used by marketing participants in identifying different varieties of dates includes colour, taste, size and shape of the fruit. Some imported varieties of date fruit found in the study area are outlined in figure 2 


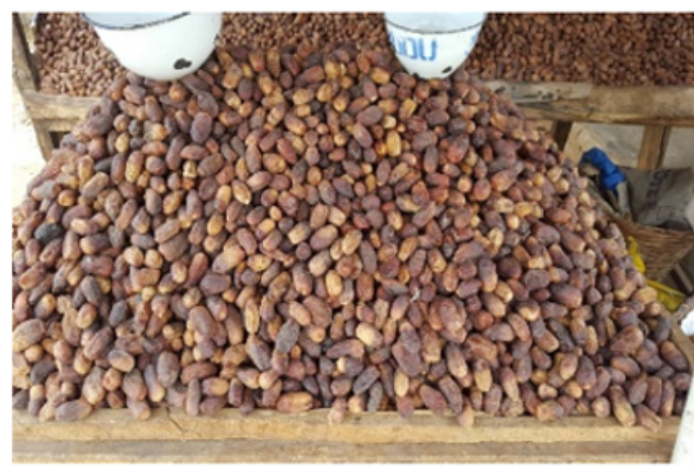

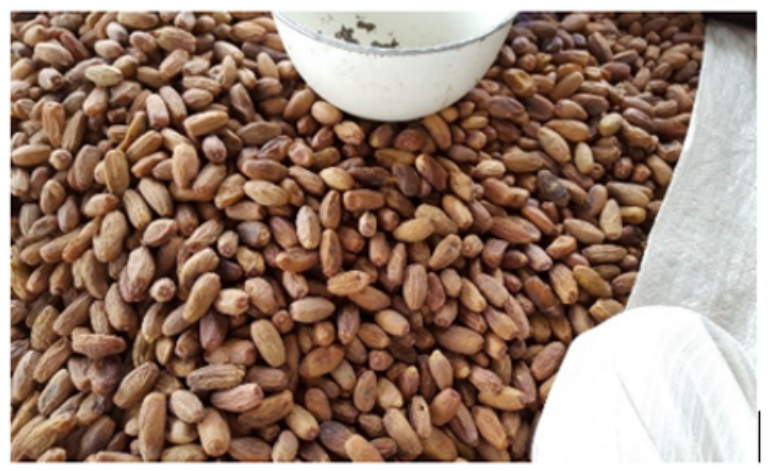

Figure 2: Some imported varieties of dates found in the study area.

(A = Dan Mali (a native of Mali), B = Dan Agadas (a native of Niger Republic).

Deglet Noor is believed to be a native of Algeria; it is semi-dry and not moderately sweet. The centre of the fruit appears light or golden when held up to the sun according to traders. Dan Mali (empress) as the name implies is a native of Mali. It is bigger, a bit softer and sweeter than Deglet Noor. It has a light tan top half and brown bottom half. Dan Agadas is from Niger republic and is the sweetest among foreign dates. It is a bit hard and has a very dark brown skin.

Deglet Noor is the most preferred date palm variety in the surveyed markets. This is because it is cheaper and readily available at the bulking market, and less susceptible to attack by termites and other storage pests. Deglet Noor is not too sweet when compared to other cultivars available in the market, this also makes it the most consumer preferred type of date.

The local varieties include Dan Shuwarin, Gaude, Takanda, Sinasir, Tsakiya, Siki, Tafarnuwa, Zabiya, Lubiya, Kura-kura, citta, etc., and are mostly sold in fresh and dry forms. Some local dates found in the study area are presented in figure 3.

A

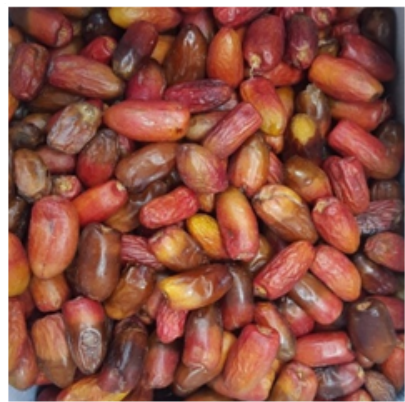

$\mathrm{D}$

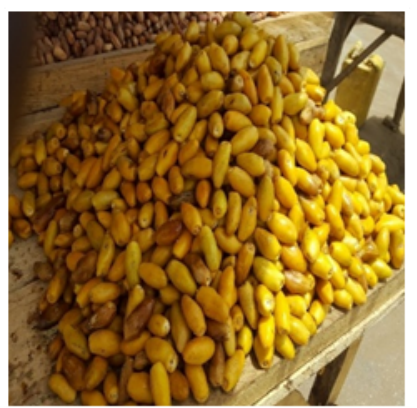

B

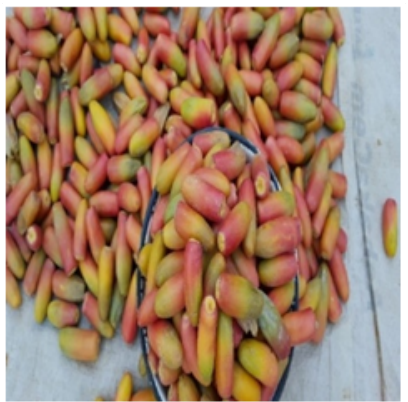

E

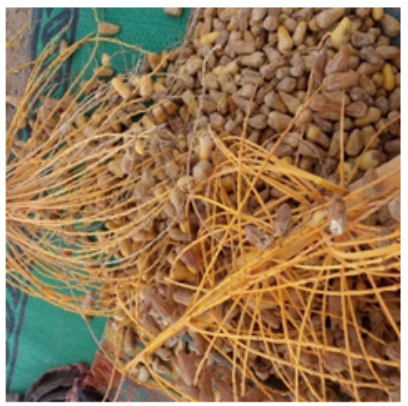

$\mathrm{C}$

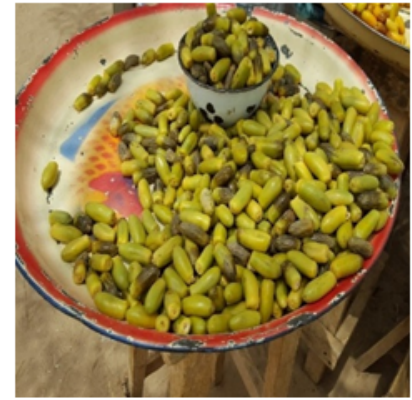

F

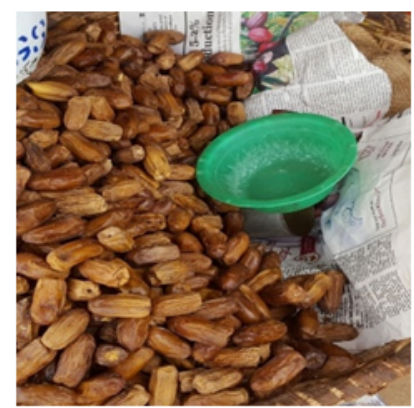

Figure 3: Some local varieties of dates found in the study area.

$(\mathrm{A}=$ Zabiya, $\mathrm{B}=$ Takanda, $\mathrm{C}=$ Gaude, $\mathrm{D}=$ Lubiya, $\mathrm{E}=$ Dan shuwarin, $\mathrm{F}=$ Chocolate $)$

Dan Shuwarin is one of the most important local date variety cultivated in the study area. It is semi-dried, soft a bit fleshy and not too sweet. This variety is found in many northern parts of Nigeria particularly during Ramadan as it competes fairly well with the foreign dates.

Zabiya is another local variety of dates found in some of the surveyed markets. It is fresh, succulent and red 
in colour. Some traders reported that this variety has appeal among the royal class of the state as it is often purchased and given as gift by the Emir of Dutse.

Takanda is another important fresh local date variety. The green colour of the variety makes it look unripe to the eyes, but it is the sweetest among the local dates found in the surveyed area.

\subsubsection{Market Information}

Marketing information, otherwise called market intelligence is the knowledge that enables market participants to take decisions in relation to their marketing activities. Efficient market information is paramount for accurate, confident and rational decision making. Wholesalers and retailers more often than not obtain market information from importers and co-traders. Traders and buyers usually engage in and try to take advantage of market situations through negotiations and haggling. According to traders, date palm has a fairly regular price and majority of the traders are aware of when prices are likely to go up, mostly during the holy month of Ramadan and sometimes Dhulhajj due to high demand in these periods when Muslims fast and perform pilgrimage, respectively. Prices are said to fall during harvest of new fruits, usually around Muharram (new month of Islamic calendar). This indicated the existence of cyclical fluctuations in date palm marketing with peak cycle experienced in the month of Ramadan and sometimes Dhulhajj and off-peak cycle around the month of Muharram.

\subsubsection{Marketing channel of date palm}

The date palm marketing channel identified in the study area revealed the participation of five (5) actors; importers, wholesalers, commission agents, retailers and consumers. These participants were involved in channeling date palm from the farmers and other sources to the consumers across the surveyed markets. At every stage of the channel, the participants perform marketing functions such as loading/offloading, storage and transportation. Figure 4 shows the marketing channel of date palm in the study area.

Marketing channel of local dates

Local dates are obtained directly from farmers within the state. Fresh dates are usually passed down to wholesalers, who in turn sales to retailers and sometimes sales directly to consumers. Retailers sells fresh dates directly to consumers. Commission agents are less involved in fresh dates channeling due to its perishability and high moisture content, which makes it liable to decay, rot and spoilage. The perishability of fresh dates posed a serious threat to its economic value and thus limits its distribution to only a few neighbouring states as it does not endure long hours of transportation.

Dried and semi dried local dates on the other hand are channeled from farmers to wholesalers, from wholesalers to retailers and from retailers to consumers. Farmers sometimes sell directly to consumers. Dried dates are channeled to many states across the country by wholesalers and sometimes commission agents. The product is then passed to retailers in other states where it attracts more value than the primary producing state. Some retailers travel from their states to Jigawa state to purchase the product and take it to their respective state and sell for premium prices.

Marketing channel of foreign dates

Foreign dates found in the surveyed markets are Dan Agadas from Niger Republic, Dan Mali from Mali and Deglet Noor from Algeria. The channel of Dan Agadas begins with assemblers, who assemble the product and make it ready for up take. The channel continues with importers, who go to Niger Republic and import the product into the state. Once in the state, the importers distribute the product to wholesalers and commission agents, from whom retailers usually purchase and sell to consumers. 


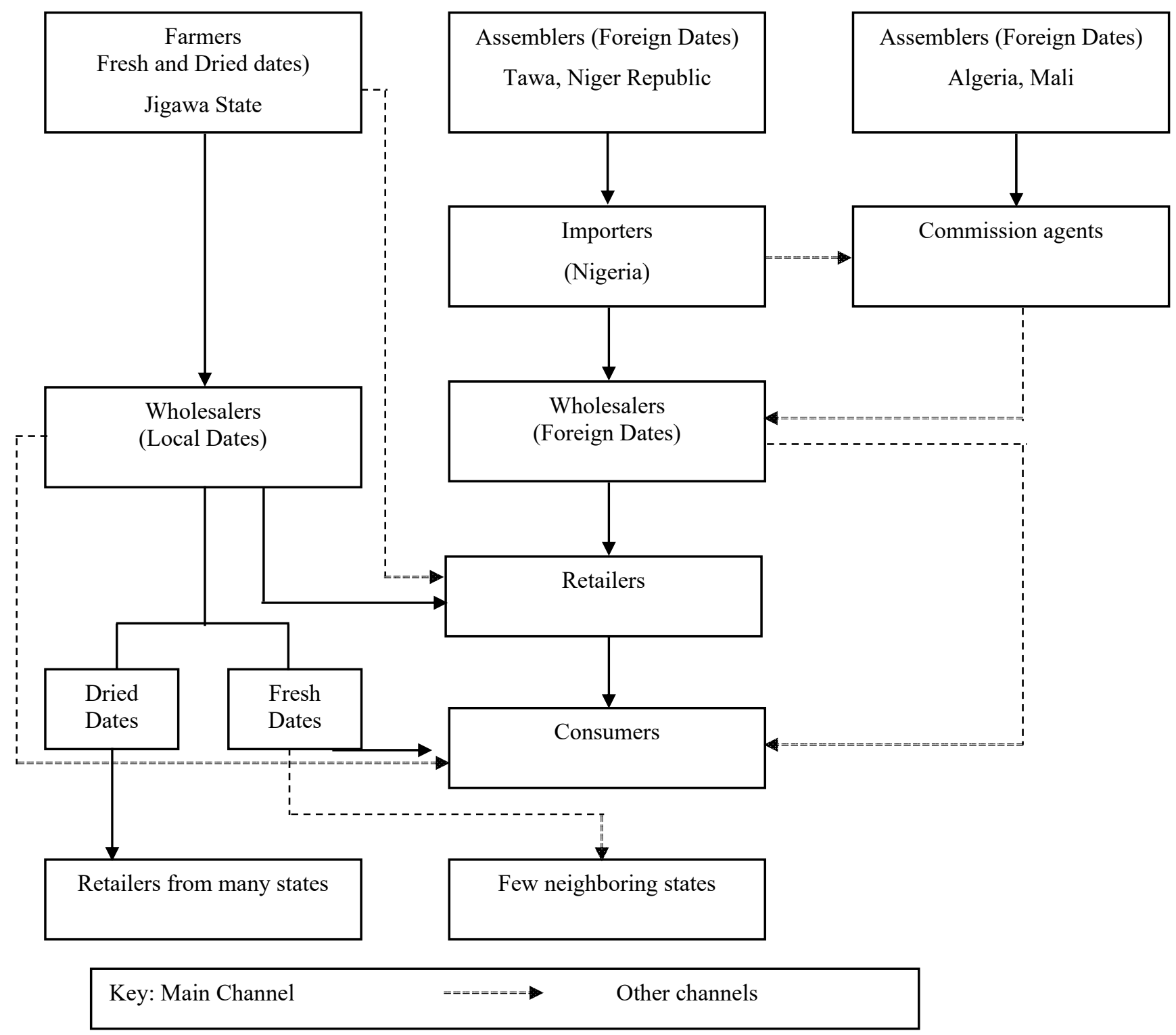

\subsubsection{Entry and exit conditions}

Figure 4: Date Palm Marketing Channel

This means the ability of a firm to enter into or leave a market at his own will without any restriction. There were no apparent restrictions to entry into and exit from date palm market as in the case with most agricultural marketing. However, high start-up capital is usually required in becoming an importer or a wholesaler. This concur with Sambo (2005) who stated that entering into or moving to another status in Gum Arabic marketing is influenced by size of capital. An exception to this was however reported by few traders where exist such conditions as agreement on standard selling price in accordance with same standard method of measurement, presentation of guarantor (in the wake of insurgency) prior to registration and acquisition of shop/shade from Chairman of the market association. The study further noticed that kinship, honesty, experience to a certain degree, influenced the conduct of date palm marketing in the study area, since a given percentage of the transactions are carried out on credit. Some interviewed traders revealed that size of capital, kinship and honesty play an integral role in entering into date palm marketing. Thus, the conduct of date marketing amongst participants is guided by kinship and honesty. There were no exit conditions in the market.

\subsection{Constraints of Date Palm Marketing}

Date palm marketing in the study area is associated with numerous problems. Table 6 presents in order of importance, the constraints encountered by date palm traders. 
Table 6: Constraints associated with date palm marketing

\begin{tabular}{|l|c|c|}
\hline Constraints & Percentage & Ranking \\
\hline Pest infestation & 22 & $1^{\text {st }}$ \\
\hline Increased cost of transportation & 17 & $2^{\text {nd }}$ \\
\hline Inadequate capital & 15 & $3^{\text {rd }}$ \\
\hline Lack of storage facilities & 13 & $4^{\text {th }}$ \\
\hline Default on credit & 11 & $5^{\text {th }}$ \\
\hline Cyclical market fluctuations & 10 & $6^{\text {th }}$ \\
\hline Lack of government support & 8 & $7^{\text {th }}$ \\
\hline Inadequate shops & 4 & $8^{\text {th }}$ \\
\hline Total & $\mathbf{1 0 0}$ & \\
\hline
\end{tabular}

Source: Field survey, 2018

Results from Table 6 revealed date fruits are subject to numerous attacks by pests to mention a few; old world date mite, banks grass mite, parlatoria date scale, among others. Damages caused by these pests can result to huge economic loss of date palm as affirmed by 22 percent of the respondents; it ranked $1^{\text {st }}$ among constraints militating against date palm marketing in the study area. According to the traders, constraints of pest attack are more prevalent on fresh dates and/or when the fruits are not stored under appropriate conditions and not dried to the appropriate moisture that will ensure that it is not prone to pest attack in the storage environment. Thus, sorting of the fruits must be done before selling resulting to further loss in quantity which will in turn deter its profitability. Constraint of pest can further be attributed to lack of good storage and preservative facilities.

Similarly, the importance of transportation in marketing cannot be over stressed. Thus, for a product to be transported or moved either from farm, other countries or neighbouring states to markets or final place of consumption, transportation cost most be incurred. Increased transportation cost ranked second as the most important constraints associated with date palm marketing in the surveyed markets. This is affirmed by 17 percent of the respondents and its ranking of the $2^{\text {nd }}$ most important constraints of date palm marketing. The increase resulted in the difficult economic situation facing the country which resulted in the removal of fuel subsidy and the fall of the national currency (naira) in the international global trade market.

Additionally, 15 percent traders reported that they find it difficult to save in order to inject funds into their businesses due to low or inadequate capital, thus its ranking as the $3^{\text {rd }}$ most important constraint bedeviling date palm marketing in the study area. As a result, date palm traders, especially retailers have low propensity to save. The fact that traders run business and consumption cycles concurrently mean that small scale traders may be stuck in vicious cycle of poverty (low savings - low investment - low return). Although some of the retailers obtain goods on credit from wholesalers, they did not enjoy any financial support from government, nongovernmental organizations and financial institutions.

\subsection{Conclusion}

The study has successfully analyzed the market structure and conduct of date palm in Jigawa state, Nigeria. All the traders were male, mostly married and within the mean age of 39 years. Majority (42.6\%) of the wholesalers had no formal education, with 12-21 years of marketing experience, while $43.3 \%$ of the retailers had only attended primary school with 2-11 years marketing experience. High inequality was observed at both wholesale $(0.75 \& 0.78)$ and retail $(079 \& 0.75)$ levels. Pest infestation, increased transportation cost and inadequate capital were the major constraints observed. The study recommends the development of improved date palm varieties that will be able to withstand pests and diseases, in addition to provision of appropriate storage, processing, credit and market facilities by all stakeholders, increased local production to boost marketable surpluses to offset demand and ensure all year-round supply of the product and reduced importation of date fruits.

\section{Acknowledgements}

Many thanks to the date palm traders in Jigawa state, particularly those in Babaldo, Gujungu, Maigatari and Shuwarin markets for their cooperation in providing the information required for the study.

\section{Conflicts of interest}

The authors declare no conflict of interest and the study was fully funded by the combined effort of the authors.

\section{References}

Abdu, Z. (2006). Economics of Soybean Marketing in Guinea Savannah, Nigeria. An Unpublished Ph. D Thesis. Agricultural Economics and Extension Programme, Abubakar Tafawa Balewa University, Bauchi.

Abdulqadir, I. M., Garba, I. D., Eseigbe, E. and Omofonmwan, E. I. (2011). Nutritional Components of Date Palm and its Production Status in Nigeria. Agricultural Economics Division, Nigerian Institute for Oil Palm 
Research (NIFOR). International Journal of Agricultural Economics and Rural Development., 4 (2), 83-89.

Abdulsalam, Z. (2004). Economics of Cross-Border Food Grain Marketing between Nigeria and Niger Republic. An Unpublished Ph. D Thesis, Ahmadu Bello University, Zaria, Nigeria.

Acharya, S. S. And Agarwal, N. L. (2006). Agricultural Marketing in India, Sixth Edition, Oxford \& IBH Publishing Co. Pvt. Ltd. New Delhi. Pp.23-26.

Adamu, M. B. (2013). Socio-economic Characteristics of Farers under National Fadama Development Project in Billiri Local Government Area of Gombe State, Nigeria. Journal of Agricultural Science Research , 1 (2): 7-21.

Adeoye, I.B, Odeleye, O.M.O., Babalola, S.O. and Afolayan, S.O. (2009). Economic Analysis of Tomato Losses in Ibadan Metropolis, Oyo State, Nigeria". African Journal of Basic and Applied Sciences, National Horticultural Research Institute Vol. 1(5-6). Pp.87-92.

Adesina, A. C. and Kehinde, A. I. (2008). Economics of Wholesale Marketing of Fruits in Ibadan Metropolis of Oyo State, Nigeria. In: Umeh, J. C, Obinne, P. and Lawal, L. (eds). Prospects and Challenges of Adding Value to Agricultural Products. Proceedings of $22^{\text {nd }}$ Annual National Conference of Farm Management Association of Nigeria.

Ajala, M.K. Adesehinwa, A.O.K. (2008). Analysis of Pig Marketing in Zango Kataf Local GArea of Kaduna State, Niheria. Journal of Tropicultura. 26 (2): 229-239.

Ataga. C. D., Mohammed. A. H. and Yusuf. A. O. (2012). Status of Date Palm (Phoenix dactylifera L.), Plant Breeding Division, Nigerian Institute for Palm Oil Research (NIFOR), Benin City. International Journal of Life Science and Pharma Research, 2(2250-0480), 2: 46-51.

Biran, G. M. (1995). Economics of Resource Use in Small Scale Agricultural Production: A Case of Cotton Farms in Akko Local Government Area of Bauchi State. An Unpublished M. Sc. Thesis, Agricultural Economics and Extension Programme, Abubakar Tafawa Balewa University, Bauchi, Pp 68.

Blessing, A. and Shulammite, A. (2012). Marketing Analysis of Rice in Udu Local Government Area, Delta State. Continental Journal of Agricultural Economics, 6 (2): 21-31.

Dada, M., Nwawe, C. N., Okere, R. A. and Uwubanmwen, I. O. (2012). Potentials of Date Palm Tree to the Nigerian Economy, Agricultural Economics Division, Nigerian Institute for Oil Palm Research (NIFOR). World Journal of Agricultural Sciences, 8 (3)(1817-3047), 309-315.

Ejembi, E. P., Ejembi, S. A. and Abgulu, O. N. (2006). Food Chain Activities of Women in an Agrarian Community of Central Nigeria: Implications for Rural Development. Journal of Human Ecology. 19(1). 6367.

Food and Agricultural Organization of the United Nation (FAO) (1993). Palm Products (excluding dates). Available at http://www.fao.org/docrep/t0681E/t0681e10.htm. Accessed October $25^{\text {th }} 2018$.

Gajendran, K. And Kathiravan, G. (2008). Structure of Duck Egg and Meat Marketing System: The Case of Tamil Nadu (South India). World Applied Science Journal, 3 (1): 63 - 66.

Ham, C. (2003). Indigenous fruit commercialization in selected SADC. Background report prepared for ICRAF Southern Africa. Commercial Products from the World Consortium. Pp.19

Handiganur, S.S., and Kunnal, L.B. (1999). Market Structure for Chickpea in Different Markets of Karnataka. Indian Journal of Agricultural Marketing, 13 (3): 28 - 33.

Jigawa State Agricultural and Rural Development Authority (JARDA, 2005). 2005Annual Report.

Kibiego, M. B., Odhiambo, M. O., \& Kimani, P. M. (2003). Analysis of Beans Marketing System in Urban Areas of Kenya. African Crop Science Conference Proceedins. Vol. 6: 587 - 590.

Kumar, B and Gogoi, M. (2011). A case study on consumer buying behavior and brand loyalty with regard to processed liquid packed milk in Guwahati, Assam. Indian Journal of Marketing, 41(5):48-52.

Makerere, A. P. (2004). Farmers Perception of the Role of Extension Organizations in Agricultural Development in Nasarawa Local Government Area of Nasarawa State. An Unpublished B. Agric. Tech. Thesis, Agricultural Economics and Extension Programme, Abubakar Tafawa Balewa University, Bauchi. Pp 124.

Mandanna, P.K., URS, D-S. D., and Achoth, L. (1998). Structure Change in India's Tobacco Exports: A Markov Chain Approach. Tropical Agriculture Research, 10: $134-143$.

Mkonda, A., Ramdhani, T., Mafongaya, P. L., \& Jere, I. (2003). Marketing Potentials of Indigenous Fruits of Miombo Woodlands of Southern Africa: A Case of Uapaca Kirkiana Fruits in Eastern Zambia. ICRAF.

Muhammed, A. Y. (2012). Economic Analysis of Gum Arabic Markets in Kano State, Nigeria. An Unpublished Ph.D. Thesis, Department of Agricultural Economics and Extension, Bayero University, Kano. Pp. 100 102.

Mundinamani, S.M., Sastry, N.R., and Murthy Shankar, H.G. (1993). Market Structure for Oilseeds in Karnataka: A Case of Groundnut. Indian Journal of Agricultural Marketing, 7 (2): 201 - 212.

Nambiro, E., de Groote, H. and Kosura, W.O. (2001). Market structure and conduct of the hybrid maize seed industry, A case study of the Trans Nzoia district in western Kenya. Seventh Eastern and Southern Africa Regional Maize Conference, $11^{\text {th }}-15^{\text {th }}$ February, 2001. pp. 474-479 
NPC. (2006). National Population Census, 2016. Enumerators Manual. National Population Commission, Abuja, Federal Republic of Nigeria. Pp 90.

Okolo E. C., Okwuagwu C. O. and Ataga C. D. (2005). Prospect of Date Plantation Establishment in Nigeria. Journal of Agric Forestry and Fisheries, 6: 1: 24-28.

Okwoche, V. A. O., Obinna, C. P. O. and Orbude, A. K. (2010). An Evaluation of Agricultural Information System Among Members of Farmer' Community-Based Organizations in Nigeria's Food Basket State. Journal of Agriculture. 5(6): 338-341.

Olukosi J.O, Isitor S.U and Ode. M. O. (2005). Introduction to Agricultural marketing and Prices: Principles and Applications, Living Book Series. Abuja, Nigeria.: G.U Publications.

Omoti, U. and Okolo, E. C. (2000). Date Palm Research in Nigeria: Progress and Priorities. Proceedings of Date Palm International Symposium, Windhoek, Namibia.

Padmanabhan, N.R., and Sankaranarayanan, K. (1999). Business experience, product lines of dealers and farmers loyalty to dealer for pesticides in Southern Tamil Nadu. Indian Journal of Agricultural Marketing, $13(3): 69-74$.

Ramadhani, T. and Schmidt, E. (2002). Marketing Analysis of Uapaca kirkiana indigenous fruits in Zimbabwe: Which is the way forward? Paper presented at the Regional Agroforestry Conference "Agroforestry Impacts on Livelihoods in Southern Africa: Putting Research into Practice" Warmbaths, South Africa, May 20-24. Pretoria, South Africa.

Salman, A. (2011). Date Palm Market Chain and Its Role in Food Security and Livelihoods of Farmers in South Punjab. M.Sc Thesis, Department of Agric. Extension, University of Agriculture, Faisaabad.

Sani, L. M. (2009). Exploring the Nigerian Date Palm (Phoenix dactylifera, L.) Germplasm for In vitro Collagensis.

Takele, A. (2010). Analysis of Rice Profitability and Marketing Chain: The Case of Fogera Woreda, South Gondar Zone, Amhara National Regional State, Ethiopia. M.Sc. Thesis. Thesis submitted to Haramaya University.

Uloh, E. V., \& Alimbo, J. O. (2018). Market Structure and Conduct of Banana Fruits Marketing in South East Nigeria. Contemporary Jornal of Interdisciplinary Studies (COJIS) 17(4): www.cojisonline.org. accessed $01 / 03 / 2021$.

Usman, S. (2009). Resource use Efficiency in Sesame Production in Jigawa State. An Unpublished M. Sc. Thesis, Department of Agricultural Economics and Rural Sociology, Ahmadu Bello University, Zaria. Zaria.

Yusefu, A.O, and Ayanwale, A.B. (2011). Structure, Conduct and Profitability of Broiler Processing Enterprises in South Western Nigeria. Learning Publics. Journal of shift Agriculture and Environmental Studies, (2 (2): $1-20$.

Zaid, A. and Wet, P. F. (2002). Origin, Geograohical Distribution and Nutritional Value of Date Palm. In Zaid. A, (ed.) Date palm cultivation. FAO Plant Production and Protection Paper. 156: 39.

Kabir Abdulaziz, Ph.D. Agricultural Economics, Chaudhary Charan Singh Haryana Agricultural University, Hisar, India (2018 - to - Date); M.Sc. Agricultural Economics, Bayero University, Kano, Nigeria (2014 - 2017); B. Agriculture, Usmanu Danfodiyo University, Sokoto, Nigeria (2003 - 2008). Member, Agricultural Society of Nigeria (ASN) in 2018. Kabir have been working with Agricultural research Council of Nigeria, Abuja from 2011 to date.

Amina Mustapha is happily married and blessed with four children. Ph.D. Agricultural Economics, Bayero University, Kano (2012), M.Sc. Agricultural Economics, University of Ibadan (1998); and BSc. Agriculture, Usmanu Danfodiyo University, Sokoto (1994). Amina was employed as a Lecturer II in Bayero University in the year 2002 where she rose through the ranks to become a Professor of Agricultural Economics in 2018. Her field of specialization is Agricultural Marketing and Value Chain Analysis. Amina was a Deputy Director at the Centre for African Entrepreneurship Research and Training for three years from where she was appointed the Deputy Director, Outreach and Publications in the Centre for Dryland Agriculture in 2015 where she is till date. She is also the Monitoring and Evaluation Officer of the Africa Centre of Excellence (ACE) Project in the Centre.

Aminu Suleiman Ph.D. Agricultural Economics, (2007), M.Sc. Agricultural Economics (2001) and B. Agriculture (1995) respectively from Ahmadu Bello University, Zaria Nigeria. He is currently a Professor of Agricultural Economics with Department of Agricultural Economics and Extension, Faculty of Agriculture, Bayero University, Kano. In addition to developing many training modules and formulation of agricultural Investment work plans, he has served as a consultant to many local and International Agricultural organizations in addition to having 23 years of experience in agricultural research. He has to his credit 27 published journal articles and 35 technical reports which emanated from researches carried out either individually or jointly with many multidisciplinary research teams. He supervised $4 \mathrm{PhD}, 17 \mathrm{MSc}$, conducted $3 \mathrm{PhD}$ internal examinations and over 30 undergraduate projects. He conducted external examinations to $7 \mathrm{PhD}$ and $17 \mathrm{MSc}$. 
Ashafa Salisu Sambo, Ph.D. Agricultural Economics (Livelihood and Natural Resource Economics), Bayero University, Kano, Nigeria (2020 to date); M.Sc. Agricultural Economics, Bayero University, Kano, Nigeria (2014 to 2017); B. Agric. Tech. (Agricultural Economics and Extension), Abubakar Tafawa Balewa University, Bauchi, Nigeria (2005 to 2011). Ashafa have been working with Nuhu Bamalli Polytechnic, Zaria, Samaru-Kataf Campus, Nigeria.from January 2014 to date.

Mohammed Mustapha Bada, Ph.D. Agricultural Economics, University of Maiduguri, Borno State, Nigeria (2017 to 2021); M.Sc. Agricultural Economics, Bayero University, Kano, Nigeria (2014 to 2017); B. Agric. (Agric. Econs. Hons.), University of Maiduguri, Borno State, Nigeria (2005 to 2011). Mohammad have been working with Bank of Agriculture (BOA), Maiduguri, Nigeria from 2016 to date. 